This PDF is a selection from an out-of-print volume from the National Bureau of Economic Research

Volume Title: International Volatility and Economic Growth: The First Ten Years of The International Seminar on Macroeconomics

Volume Author/Editor: Georges de MÃ@nil and Robert J. Gordon, editors

Volume Publisher: Elsevier Science Publishers B.V., 1991

Volume ISBN: 0-444-89284-2

Volume URL: http://www.nber.org/books/de_m91-2

Conference Date: various

Publication Date: January 1991

Chapter Title: The Collapse of Purchasing Power Parities During the 1970s

Chapter Author: Jacob A. Frenkel

Chapter URL: http://www.nber.org/chapters/c11681

Chapter pages in book: (p. 217 - 237) 


\title{
THE COLLAPSE OF PURChASING POWER PARITIES DURING THE 1970's*
}

\author{
Jacob A. FRENKEL** \\ NBER, and The University of Chicago, IL 60637, USA
}

\section{Introduction}

One of the striking facts concerning the relationship between prices and exchange rates during the 1970's has been the dismal performance of the predictions of the simple versions of the purchasing power parity doctrine (PPP). That doctrine in its 'absolute version' states that the equilibrium exchange rate between domestic and foreign currencies equals the ratio of domestic to foreign price levels. The 'relative version' of the doctrine relates equilibrium changes in exchange rates to changes in the ratio of domestic to foreign prices. During the 1970's short-run changes in exchange rates bore little relationship to short-run differentials in national inflation rates and, frequently, divergences from purchasing power parities have been cumulative.

This paper reviews and analyzes the empirical record of exchange rates and prices during the 1970's and the analysis is based on the experience of the Dollar/Pound, the Dollar/French Franc and the Dollar/DM exchange rates. Section 2 presents the evidence on PPP during the 1970's and contrasts it with the evidence from the 1920's - a period during which the doctrine held up reasonably well. This analysis is relevant for assessing whether the flexible exchange rate system was successful in providing national economies with an added degree of insulation from foreign shocks, and whether it provided policymakers with an added instrument for the conduct of macroeconomic policy. The evidence regarding deviations from purchasing power parities is also relevant for determining whether there is a case for managed float. Section 3 attempts to explain what went wrong with

\footnotetext{
*An earlier version of this paper was presented at the International Seminar in Macroeconomics, Oxford, June 22-24, 1980, and sponsored by the National Bureau of Economic Research, Inc. and the Maison des Sciences de l'Homme, Paris.

**I am indebted to Lauren J. Feinstone for helpful suggestions and efficient research assistance and to Robert $\mathbf{J}$. Gordon for many useful suggestions which stimulated this version of the paper. I also wish to acknowledge a National Science Foundation grant, SOC 78-14480, for financial support. This research is part of the NBER's Program in International Studies. The views expressed are those of the author and not necessarily those of the NBER.
} 
the performance of the doctrine during the 1970's. It examines the hypothesis that the departures from PPP are a U.S. phenomenon, as well as the hypothesis that the departures are due to large changes in inter-sectoral relative price changes within the various economies. Given that the predictions of the simple versions of PPP do not hold up, section 4 proceeds in examining the question of whether national price levels have been independent of each other. Section 5 addresses the question of whether exchange rates and national price levels are comparable and whether in principle one should have expected them to be closely linked to each other. The main point that is being emphasized is that there is an important intrinsic difference between exchange rates and national price levels which stems from the 'asset market theory' of exchange rate determination. This theory implies that the exchange rate, like the prices of other assets, is much more sensitive to expectations concerning future events than national price levels and as a result, in periods which are dominated by 'news' which alter expectations, exchange rates are likely to be much more volatile than national price levels and departures from PPP are likely to be the rule rather than the exception. Finally, section 6 concludes the paper with some policy implications.

\section{Purchasing power parities: The evidence}

The relationship between exchange rates and prices that is summarized by the PPP doctrine is one of the oldest and the most controversial relationships in the theory of exchange rates. The intellectual origins of the doctrine [which are analyzed in Frenkel (1978)] can be traced back to the writings of Wheatley and Ricardo in the early part of the 19th century and its more recent revival owes much to Cassel's writings mainly during the 1920 's. Much of the controversy concerning the usefulness of the PPP doctrine is due to the fact that it does not specify the precise mechanism by which exchange rates are linked to prices nor does it specify the precise conditions that must be satisfied for the doctrine to be correct. Rather, the PPP doctrine may be viewed as a short-cut; it specifies a relationship between two variables without providing the details of the process which brings about such a relationship and, therefore, it should not be viewed as a theory of exchange rate determination.

\subsection{Empirical framework}

The PPP relationship can be written as

$$
\ln S_{t}=a+b \ln \left(P / P^{*}\right)_{t}+u_{t}
$$


where $S_{t}$ and $\left(P / P^{*}\right)_{t}$ denote, respectively, the exchange rate (defined as the price of foreign exchange in terms of domestic currency), and the ratio of domestic to foreign price indices (with an asterisk denoting quantities pertaining to the foreign country) and where $u_{t}$ denotes an error term. The formulation in eq. (1) corresponds to the absolute version of PPP. The corresponding relative version of PPP can be written as

$$
\Delta \ln S_{t}=b \Delta \ln \left(P / P^{*}\right)_{t}+v_{t}
$$

where $\Delta$ denotes the first difference operator and where $v_{t}$ denotes an error term.

From the empirical viewpoint several issues may be raised: (i) What price index should be used in eqs. (1)-(2)? (ii) Are the data consistent with the hypothesis that $b=1$ ? (iii) Is the constant term in the relative version of PPP zero as implied by eq. (2)? Further refinements would also examine whether the coefficients on domestic and foreign prices are equal to each other (in absolute value) as implied by the specification of eqs. (1)-(2). These questions are examined below using monthly data for the U.S., the U.K., France and Germany. To allow for a simultaneous determination of prices and exchange rates, eqs. (1)-(2) are estimated using a two-stage least squares estimation procedure.

\subsection{The evidence from the 1920's}

In order to fix ideas and to provide perspective for the evaluation of the empirical record of the 1970's, it is useful to start with a brief review of the performance of PPP during the flexible exchange rates period of the 1920's. The experience with flexible exchange rates during the 1920's (which was terminated with the return of Britain to gold in mid-1925) has proven to be extremely important in shaping current thinking about a variety of issues concerning the economics of flexible exchange rates and has been critical for the growth of popularity of the PPP doctrine. That period included experiences under hyperinflationary conditions (the German hyperinflation) as well as under 'normal' conditions (based on the experience of Britain, the U.S. and France).

Estimates of eq. (1) for the 1920's using alternative price indices are reported in table $1 .^{1}$ These estimates indicate that in most cases the data are consistent with the hypothesis that the elasticity of the exchange rate with respect to the price ratio is about unity. ${ }^{2}$ In assessing these results it is

\footnotetext{
${ }^{1}$ This paragraph draws on Frenkel (1980).

${ }^{2}$ In applying eq. (2) to the hyperinflation period it was assumed that the variations in $P / P^{*}$ were completely dominated by variations in German prices so that the foreign price could be viewed as being fixed. For further evidence and tests and for the data sources, see Frenkel (1980).
} 
Table 1

Purchasing power parities: instrumental variables, monthly data during the 1920's (standard errors in parentheses)."

\begin{tabular}{llccccc}
\hline $\begin{array}{l}\text { Dependent variable } \\
\ln S_{1}\end{array}$ & Price index & Constant & $\ln \left(P / P^{*}\right)$ & s.e. & D.W. & $\rho$ \\
\hline Mark/Pound & Wholesale & -1.676 & 1.026 & 0.221 & 2.01 & 0.24 \\
(Feb. 1921-Aug. 1923) & & $(0.178)$ & $(0.017)$ & & & \\
& Cost of living & $\begin{array}{c}-1.575 \\
(0.423)\end{array}$ & $\begin{array}{c}1.084 \\
(0.041)\end{array}$ & 0.367 & 2.06 & 0.50 \\
& Wholesale & 0.562 & 1.141 & 0.044 & 1.82 & 0.53 \\
Franc/Pound & $\begin{array}{c}(0.207) \\
\text { (Feb. 1921-May 1925) }\end{array}$ & $(0.064)$ & & & \\
& Material & 0.613 & 1.081 & 0.042 & 2.18 & 0.48 \\
& & $(0.180)$ & $(0.054)$ & & & \\
Dollar/Pound & Wholesale & -0.118 & 0.897 & 0.019 & 1.99 & 0.85 \\
(Feb. 1921-May 1925) & & $(0.482)$ & $(0.267)$ & & & \\
& Material & -0.073 & 0.847 & 0.022 & 1.83 & 0.80 \\
& & $(0.453)$ & $(0.245)$ & & & \\
Franc/Dollar & Wholesale & 1.183 & 1.091 & 0.054 & 1.70 & 0.58 \\
(Feb. 1921-May 1925) & & $(0.157)$ & $(0.109)$ & & & \\
& Material & 1.243 & 0.992 & 0.050 & 1.74 & 0.54 \\
& & $(0.130)$ & $(0.085)$ & & & \\
\hline
\end{tabular}

an $S$, denotes the logarithm of the spot exchange rate. $\rho$ is the final value of the autocorrelation coefficient; an iterative Cochrane-Orcutt technique with two-stage least squares estimation method was used; the instruments are a constant, time, time squared, and lagged values of the dependent and independent variables. s.e. is the standard error of the equation.

important to recall that the estimates are based on monthly data and that short-run deviations from PPP may reflect the fact that not all markets adjust at the same speed. On the whole the results illustrate the main usefulness of the PPP doctrine. It provides a guide to the general trend of exchange rates and prices and it emphasizes that, as a first approximation, policies which affect the trend of domestic (relative to foreign) prices, are likely to affect the exchange rate in the same manner.

\subsection{The evidence from the 1970's}

In a recent paper dealing with inflation and unemployment, Gordon (1976), analyzed the reactions of a hypothetical modern-day Rip van Winkle who had become well acquainted with the earlier literature but who only recently awoke from a decade-long nap. It is interesting to examine the results of an analogous experiment in the context of PPP. Suppose that Rip van Winkle, who was well acquainted with the data reported in the previous section, went to sleep in 1925 to be awoken in the 1970's. Would his human capital of the 1920's vintage be obsolete? This question is of special interest 
since world capital markets have become much more integrated, the role of 'real' shocks and 'surprises' in the 1970's have become much more important, views about the role of government in the conduct of macroeconomic policies have changed, the roles of tariff and non-tariff barriers to trade as well as the degree of exchange rate management have been altered and finally, the International Monetary Fund has been created.

Table 2

Purchasing power parities: instrumental variables, monthly data: June 1973-July 1979 (standard errors in parentheses).

\begin{tabular}{lcccccc}
\hline $\begin{array}{l}\text { Dependent variable } \\
\ln S_{t}\end{array}$ & Constant & $\ln \left(P_{w} / P_{w}^{*}\right)$ & $\ln \left(P_{c} / P_{c}^{*}\right)$ & s.e. & D.W. & $\rho$ \\
\hline Dollar/Pound & 0.712 & 0.165 & & 0.027 & 1.63 & 0.963 \\
& $(0.149)$ & $(0.507)$ & & & & \\
& 2.982 & & 1.070 & 0.029 & 1.66 & 0.998 \\
Dollar/Franc & $(2.978)$ & & $(0.897)$ & & & \\
& -1.521 & 0.184 & & 0.029 & 2.26 & 0.863 \\
& $(0.027)$ & $(0.374)$ & & & & \\
& -1.570 & & -1.070 & 0.029 & 2.30 & 0.901 \\
Dollar/DM & $(0.047)$ & & $(0.817)$ & & & \\
& -0.900 & 1.786 & & 0.034 & 1.69 & 0.739 \\
& $(0.018)$ & $(0.230)$ & & & & \\
& -0.908 & & 2.217 & 0.031 & 1.96 & 0.759 \\
\hline
\end{tabular}

${ }^{4}$ In $S_{t}$ denotes the logarithm of the spot exchange rate; $\ln \left(P_{w} / P_{w}^{*}\right)$ and $\ln \left(P_{c} / P_{c}^{*}\right)$ denote, respectively, the logarithms of the ratios of the wholesale price indices and the cost of living indices. Cochrane-Orcutt iterative technique with two-stage least squares estimation method was used; the instruments are a constant, time, time squared, and lagged values of the dependent and independent variables. s.e. is the standard error of the equation.

Tables 2 and 3 report the estimates of eqs. (1) and (2) for the monthly Dollar/Pound, the Dollar/French Franc and the Dollar/German Mark exchange rates using wholesale and cost of living price indices. As may be seen the results are extremely poor and the estimates are extremely imprecise. For the absolute version of PPP (table 2) the coefficients on the price ratios are significant only in the equations pertaining to the Dollar/DM exchange rate, and for the relative version of PPP (table 3) the slope coefficient is again insignificant. It is noteworthy, however, that (as expected) the constant terms in that table do not differ significantly from zero. The poor performance of these versions of PPP during the 1970's is augmented by the fact that in some cases the estimates do not remain stable over the sample period. This instability is especially exhibited in the Dollar/Pound regressions. Table 4 contains estimates of the Dollar/Pound equations for the 
Table 3

Relative purchasing power parities: instrumental variables, monthly data: June 1973-July 1979 (standard errors in parentheses).

\begin{tabular}{lccccc}
\hline $\begin{array}{l}\text { Dependent variable } \\
\Delta \ln S_{1}\end{array}$ & Constant & $\Delta \ln \left(P_{w} / P_{w}^{*}\right)$ & $\Delta \ln \left(P_{c} / P_{c}^{*}\right)$ & s.e. & D.W. \\
\hline Dollar/Pound & 0.009 & 1.827 & & 0.036 & 1.53 \\
& $(0.007)$ & $(1.034)$ & & & \\
& 0.010 & & 2.071 & 0.034 & 1.59 \\
& $(0.007)$ & & $(1.084)$ & & \\
Dollar/Franc & -0.001 & 0.967 & & 0.031 & 2.35 \\
& $(0.004)$ & $(0.722)$ & & & \\
& -0.001 & & -0.030 & 0.030 & 2.36 \\
& $(0.006)$ & & $(2.800)$ & & \\
Dollar/DM & 0.004 & -0.261 & & 0.032 & 2.17 \\
& $(0.007)$ & $(1.703)$ & & & \\
& -0.002 & & $(2.305)$ & 0.034 & 2.08 \\
& $(0.008)$ & & $(2.9)$ & \\
\hline
\end{tabular}

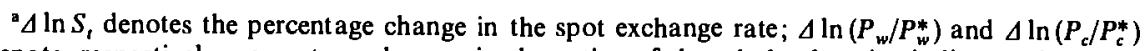
denote, respectively, percentage changes in the ratios of the wholesale price indices and cost of living indices. s.e. is the standard error of the equation. Two-stage least squares estimation method is used; the instruments are a constant, time, time squared, and lagged values of the dependent and independent variables.

Table 4

Purchasing power parities for the Dollar/Pound: instrumental variables, monthly data: June 1973-February 1979 (standard errors in parentheses). ${ }^{\mathrm{a}}$

\begin{tabular}{llcccccc}
\hline Price index & Dependent variable & Constant & $\ln \left(P / P^{*}\right)$ & $\Delta \ln \left(P / P^{*}\right)$ & s.e. & D.W. & $\rho$ \\
\hline $\begin{array}{l}\text { Wholesale } \\
\text { price }\end{array}$ & $\ln S_{t}$ & 0.726 & 0.424 & & 0.027 & 1.74 & 0.938 \\
index & & $(0.076)$ & $(0.338)$ & & & & \\
& $\Delta \ln S_{t}$ & 0.003 & & 1.032 & 0.030 & 1.71 & - \\
& & $(0.006)$ & & $(0.712)$ & & & \\
Cost of & $\ln S_{t}$ & 0.727 & 0.544 & & 0.026 & 1.83 & 0.935 \\
living & & $(0.071)$ & $(0.394)$ & & & & \\
index & $\Delta \ln S_{t}$ & 0.005 & & 1.637 & 0.030 & 1.87 & - \\
& & $(0.006)$ & & $(0.832)$ & & & \\
\hline
\end{tabular}

${ }^{a} \ln S$, and $\ln \left(P / P^{*}\right)$ denote, respectively. the logarithms of the spot exchange rate and price ratios; $\Delta$ denotes the first difference of these variables. s.e. denotes the standard error of the equation. Two-stage least squares estimation method was used; the instruments are a constant, time, time squared, and lagged values of the dependent and independent variables. CochraneOrcutt iterative technique was used with the levels. 
period up to February 1979 instead of July 1979. The comparison of these estimates with those in tables 2 and 3 illustrates the extent of the instability. ${ }^{3}$

\section{What went wrong?}

From the comparison of the evidence from the 1920's with those from the 1970 's it is obvious that if Rip van Winkle were to predict the results of table 2 from those of table 1 his predictions would have failed dramatically. What is responsible for this failure?

\subsection{Are the departures from PPP a U.S. phenomenon?}

In starting to account for the collapse of PPP in the 1970's it is first relevant to note that all the regressions in tables 2,3 and 4 involve the U.S. dollar exchange rate and the U.S. price index. In order to examine whether this fact plays an important role in yielding the poor results, the PPP equations were re-estimated for the various exchange rates which do not involve the U.S. dollar or the U.S. price level, i.e., for the Pound/DM and the Franc/DM exchange rates. These results are reported in table 5. As may be seen the results here are much superior. Except for the wholesale price indices in the Franc/DM regression, all the coefficients are highly significant

Table 5

Purchasing power parities: instrumental variables, monthly data: June 1973-July 1979 (standard errors in parentheses).

\begin{tabular}{lcccccl}
\hline $\begin{array}{l}\text { Dependent variable } \\
\ln S_{t}\end{array}$ & Constant & $\ln \left(P_{w} / P_{w}^{*}\right)$ & $\ln \left(P_{c} / P_{c}^{*}\right)$ & s.e. & D.W. & $\rho$ \\
\hline Pound/DM & -1.668 & 0.821 & & 0.027 & 1.60 & 0.895 \\
& $(0.041)$ & $(0.144)$ & & & & \\
& -1.666 & & 0.965 & 0.027 & 1.57 & 0.909 \\
& $(0.048)$ & & $(0.197)$ & & & \\
Franc/DM & 0.863 & -0.026 & & 0.020 & 1.61 & 0.981 \\
& $(0.143)$ & $(0.487)$ & & & & \\
& 0.602 & & 1.180 & 0.019 & 1.48 & 0.929 \\
& $(0.048)$ & & $(0.327)$ & & & \\
\hline
\end{tabular}

${ }^{a} \ln S$, denotes the logarithm of the spot exchange rate; $\ln \left(P_{w} / P_{w}^{*}\right)$ and $\ln \left(P_{c} / P_{c}^{*}\right)$ denote, respectively, the logarithms of the ratios of the wholesale price indices and the cost of living indices. Cochrane-Orcott iterative technique with two-stage least squares estimation method was used; the instruments are a constant, time, time squared, and lagged values of the dependent and independent variables. s.e. is the standard error of the equation.

${ }^{3}$ Further evidence on the empirical record of the PPP doctrine can be found in the various papers in the May issue of the Journal of International Economics 8, no. 2, 1978; and for surveys, see Officer (1976) and Katseli-Papaefstratiou (1979). 
and the elasticities of the exchange rate with respect to the various price indices do not differ significantly from unity.

What accounts for the vast difference in the performance of PPP among the various currencies? One explanation can be made in terms of the general presumption that due to transport cost, PPP is expected to hold better among the neighboring European countries than among each of these countries and the U.S. A second explanation can be made in terms of changes in commercial policies and non-tariff barriers to trade which have been more stable within Europe than between Europe and the U.S. A third argument, which was put forward in another context by Gordon (1977), emphasizes the unique effects of the various phases of the U.S. price controls and their gradual removal during the first half of the 1970's. A fourth argument could be made in terms of the effects of institutional agreements like the snake and later on like the European Monetary System on the degree of the intra-European flexibility of exchange rates.

\subsection{Changes in relative prices}

The formulation of the PPP doctrine in eqs. (1) and (2) did not specify which price index should be used in the computation. Of course, when the structure of relative prices in the economy remains stable, as is likely to be the case when most of the shocks are of a monetary origin, the choice of the price index is immaterial. On the other hand, when there are real shocks which alter relative prices, the choice of the price index becomes crucial.

To illustrate, suppose that the domestic and the foreign aggregate price levels are a linear homogeneous (Cobb-Douglas) function of the prices of non-traded goods, $P_{N}$, and of traded goods, $P_{T}$, like in eqs. (3)-(4),

$$
\begin{aligned}
& P=P_{N}^{\beta} P_{T}^{1-\rho}, \\
& P^{*}=P_{N}^{* \beta^{*}} P_{T}^{* 1-\beta^{*}},
\end{aligned}
$$

where $\beta$ and $\beta^{*}$ denote domestic and foreign expenditure shares on nontraded goods. From (3) and (4) the ratio of the prices of traded goods can be written as

$$
\frac{P_{T}}{P_{T}^{*}}=\frac{\left(P_{T} / P_{N}\right)^{\beta}}{\left(P_{T}^{*} / P_{N}^{*}\right)^{\beta^{*}}} \frac{P}{P^{*}}
$$

Eq. (5) links the relative price of traded goods to the ratio of the price levels through terms which summarize the internal price structures in the two economies. Suppose now that the formulation of purchasing power parities in eqs. (1) and (2) applies only to traded goods [so that $S$ equals $\left(P_{T} / P_{T}^{*}\right)$ 
plus an error term]. Using eq. (5) and adding a constant term yields

$$
\ln S_{t}=a+\beta \ln \left(P_{T} / P_{N}\right)_{t}-\beta^{*} \ln \left(P_{T}^{*} / P_{N}^{*}\right)_{t}+\ln \left(P / P^{*}\right)_{t}+u_{t}
$$

or, assuming for expository purposes that $\beta=\beta^{*}$, this becomes

$$
\ln S_{t}=a+\beta \ln \left(\frac{P_{T} / P_{N}}{P_{T}^{*} / P_{N}^{*}}\right)_{\imath}+\ln \left(P / P^{*}\right)_{\imath}+u_{i}
$$

A comparison of eq. (7) with (1) reveals that when the internal relative price structure remains stable, its neglect would not affect the relationship between the exchange rate and the ratio of aggregate price indices and its only influence would be confined to the estimate of the constant term. If, however, relative price structures do vary, then it is crucial to incorporate them explicitly into the PPP equations, and their omission introduces a specification bias.

Since the estimates in the previous tables were obtained from regressions employing aggregate price indices, it is important to examine whether relative price structures remained stable during the sample period. To examine this question it is first noted that the cost of living index contains relatively more non-traded commodities than the wholesale price index. It is likely therefore that when there are large changes in internal relative prices, these changes would be reflected in changes in the ratio of the cost of living to the wholesale price index.

Table 6 reports the estimates of regressions of cost of living indices on the wholesale price indices (as well as regressions of their rates of change) for the U.S., the U.K., France and Germany. As may be seen in all cases the elasticity of the cost of living inflation with respect to the wholesale price inflation is statistically significant but smaller than unity, while the elasticity of the level of the cost of living with respect to the wholesale price level is about unity in the U.S. and the U.K., is somewhat higher than unity in Germany and is about zero in France. These results indicate that the internal relative prices - as measured by the relationship between the cost of living and the wholesale price indices - have not changed much in the U.S. and the U.K., they have changed somewhat in Germany and have changed dramatically in France. This last observation may account for the poor performance of the PPP equation which related the Franc/DM exchange rate to the ratio of the wholesale price indices in table 5 .

The general pattern of the internal price ratios is described in figs. 1-4 which show a scatter of monthly observations of the two price indices for the U.S., the U.K., Germany and France. As is evident from the first two scatter diagrams the changes in relative prices have not been pronounced; the scatter for Germany reveals some degree of relative price variations while the 
Table 6

Cost-of-living and wholesale price indices: instrumental variables, monthly data: June 1973-July 1979 (standard errors in parentheses)."

\begin{tabular}{|c|c|c|c|c|c|c|c|}
\hline Country & $\begin{array}{l}\text { Dependent } \\
\text { variable }\end{array}$ & Constant & $\ln P_{w}$ & $\Delta \ln P_{w}$ & s.e. & D.W. & $\rho$ \\
\hline \multirow[t]{2}{*}{ U.S. } & $\ln P_{c}$ & $\begin{array}{c}-0.085 \\
(0.220)\end{array}$ & $\begin{array}{c}1.019 \\
(0.047)\end{array}$ & & 0.008 & 1.57 & 0.828 \\
\hline & $\Delta \ln P_{c}$ & $\begin{array}{c}0.003 \\
(0.002)\end{array}$ & & $\begin{array}{c}0.558 \\
(0.206)\end{array}$ & 0.004 & 1.64 & 0.035 \\
\hline \multirow[t]{2}{*}{ U.K. } & $\ln P_{\mathrm{c}}$ & $\begin{array}{c}0.091 \\
(0.200)\end{array}$ & $\begin{array}{c}0.976 \\
(0.041)\end{array}$ & & 0.007 & 1.23 & 0.924 \\
\hline & $\Delta \ln P_{c}$ & $\begin{array}{c}0.005 \\
(0.005)\end{array}$ & & $\begin{array}{c}0.601 \\
(0.339)\end{array}$ & 0.007 & 1.73 & 0.353 \\
\hline \multirow[t]{2}{*}{ France } & $\ln P_{c}$ & $\begin{array}{c}4.655 \\
(0.248)\end{array}$ & $\begin{array}{c}0.077 \\
(0.050)\end{array}$ & & 0.004 & 0.50 & 0.980 \\
\hline & $\Delta \ln P_{\mathrm{c}}$ & $\begin{array}{c}0.007 \\
(0.001)\end{array}$ & & $\begin{array}{c}0.287 \\
(0.087)\end{array}$ & 0.003 & 1.85 & 0.659 \\
\hline \multirow[t]{2}{*}{ Germany } & $\ln P_{c}$ & $\begin{array}{c}-1.434 \\
(0.675)\end{array}$ & $\begin{array}{c}1.310 \\
(0.145)\end{array}$ & & 0.006 & 1.12 & 0.905 \\
\hline & $\Delta \ln P_{c}$ & $\begin{array}{c}0.002 \\
(0.001)\end{array}$ & & $\begin{array}{c}0.414 \\
(0.154)\end{array}$ & 0.003 & 1.97 & 0.373 \\
\hline
\end{tabular}

${ }^{\mathrm{a}} \ln P_{\mathrm{w}}$ and $\ln \boldsymbol{P}_{\mathrm{c}}$ denote, respectively, the logarithms of the wholesale price and cost-of-living indices; $\Delta$ denotes the first difference of these variables. Cochrane-Orcutt iterative technique with two-stage least squares estimation method was used; the instruments are a constant, time, time squared, and lagged values of the dependent and independent variables. s.e. is the standard error of the equation.

scatter for France shows an extraordinary degree of fluctuations in the internal relative prices. Since these fluctuations have been so large, the information of fig. 4 is supplemented by fig. 5 which presents a time series of the two price indices. In view of these large changes in the internal relative prices the collapse of PPP which was reported in section 2 is much less surprising.

\section{Are national price trends independent of each other?}

The two versions of the PPP doctrine relate the exchange rate to the ratio of national price levels and changes in the exchange rate to inflationary differentials. As was argued above these relationships are likely to hold when the internal relative price structures remain relatively stable, as would be the case when the predominant source of shocks is of a monetary origin. If, however, relative prices do change - as they should when the predominant source of shocks is of a real origin - then the simple PPP versions which use aggregate price levels are not likely to hold. It is possible, however, that 


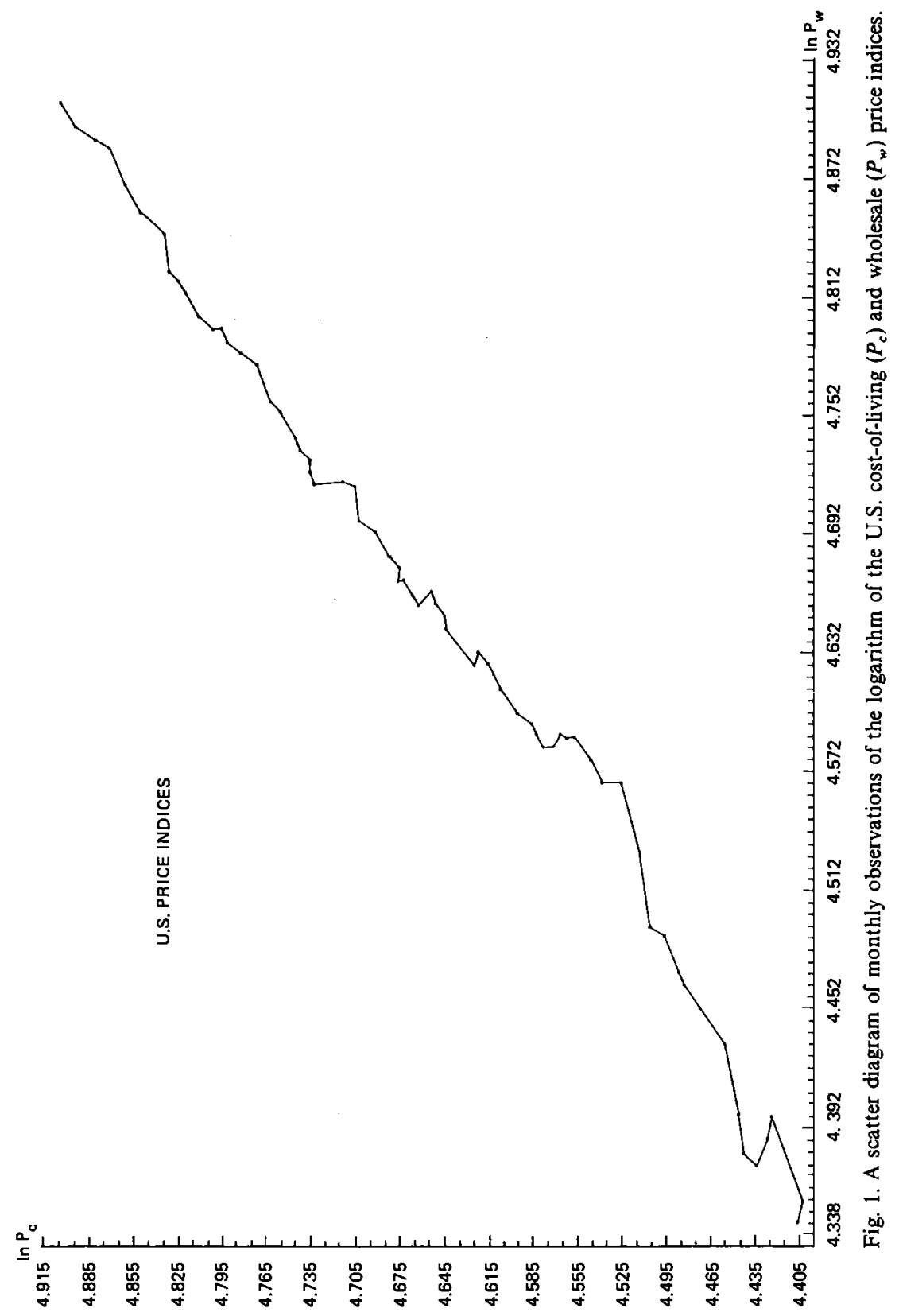




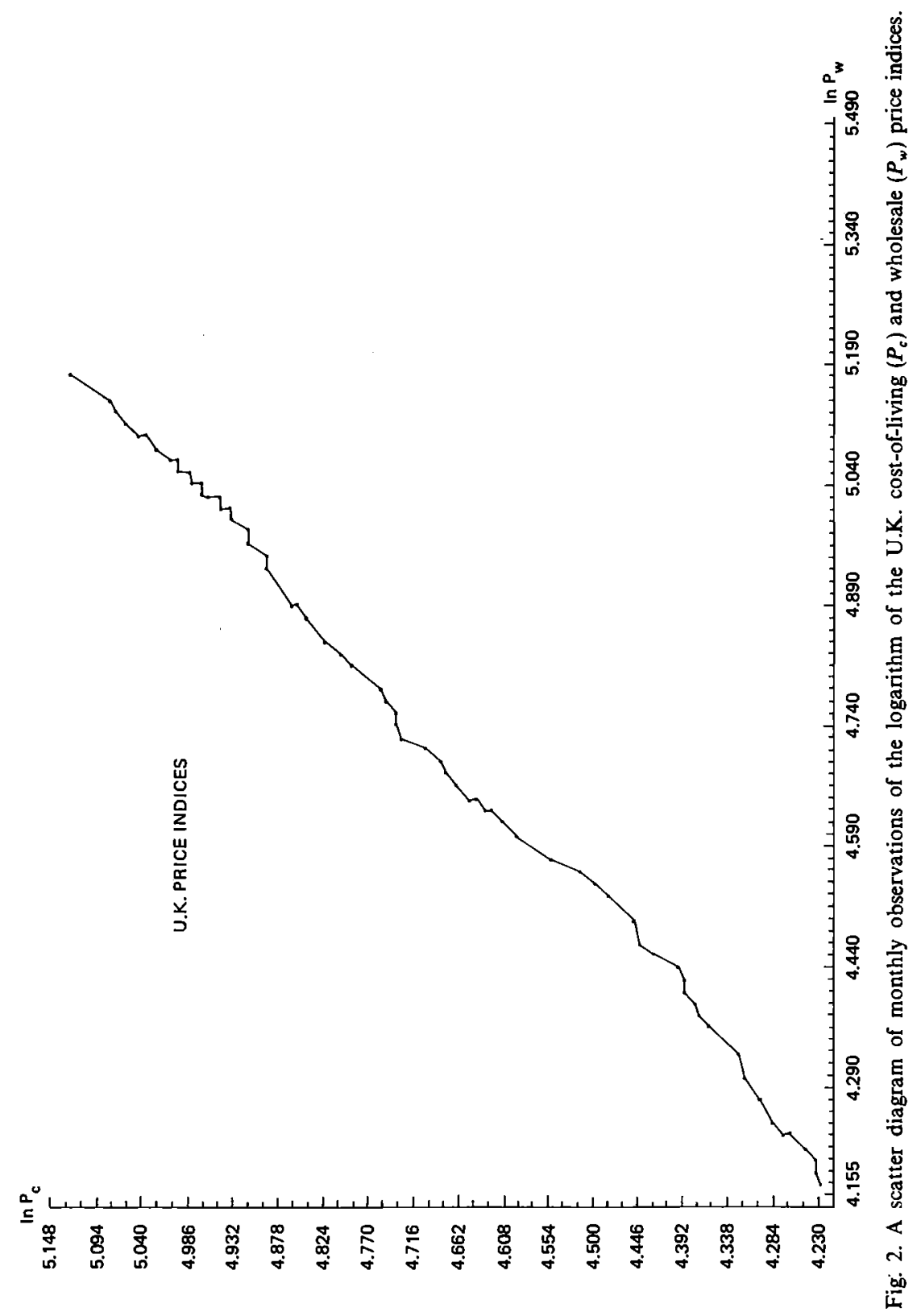




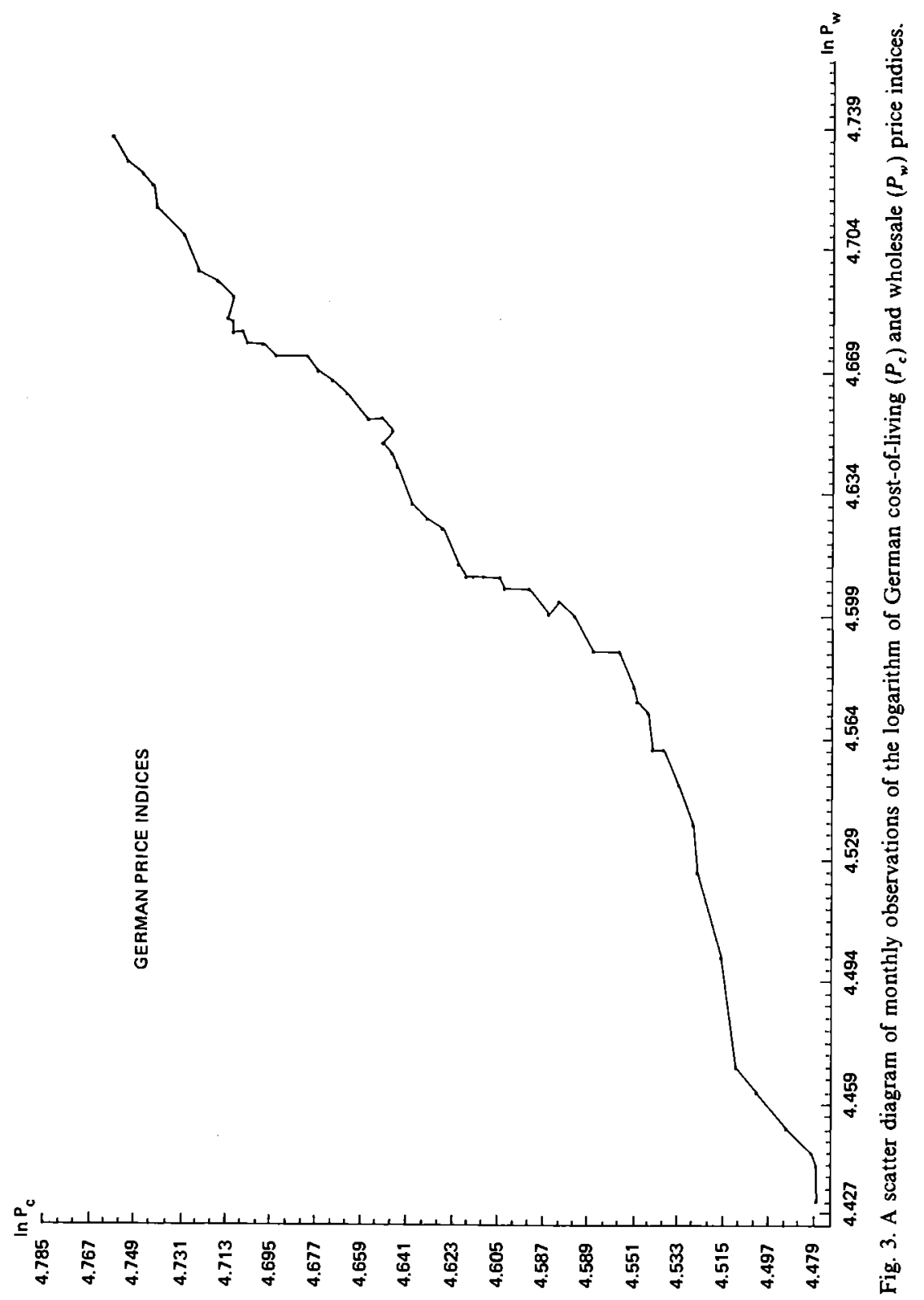




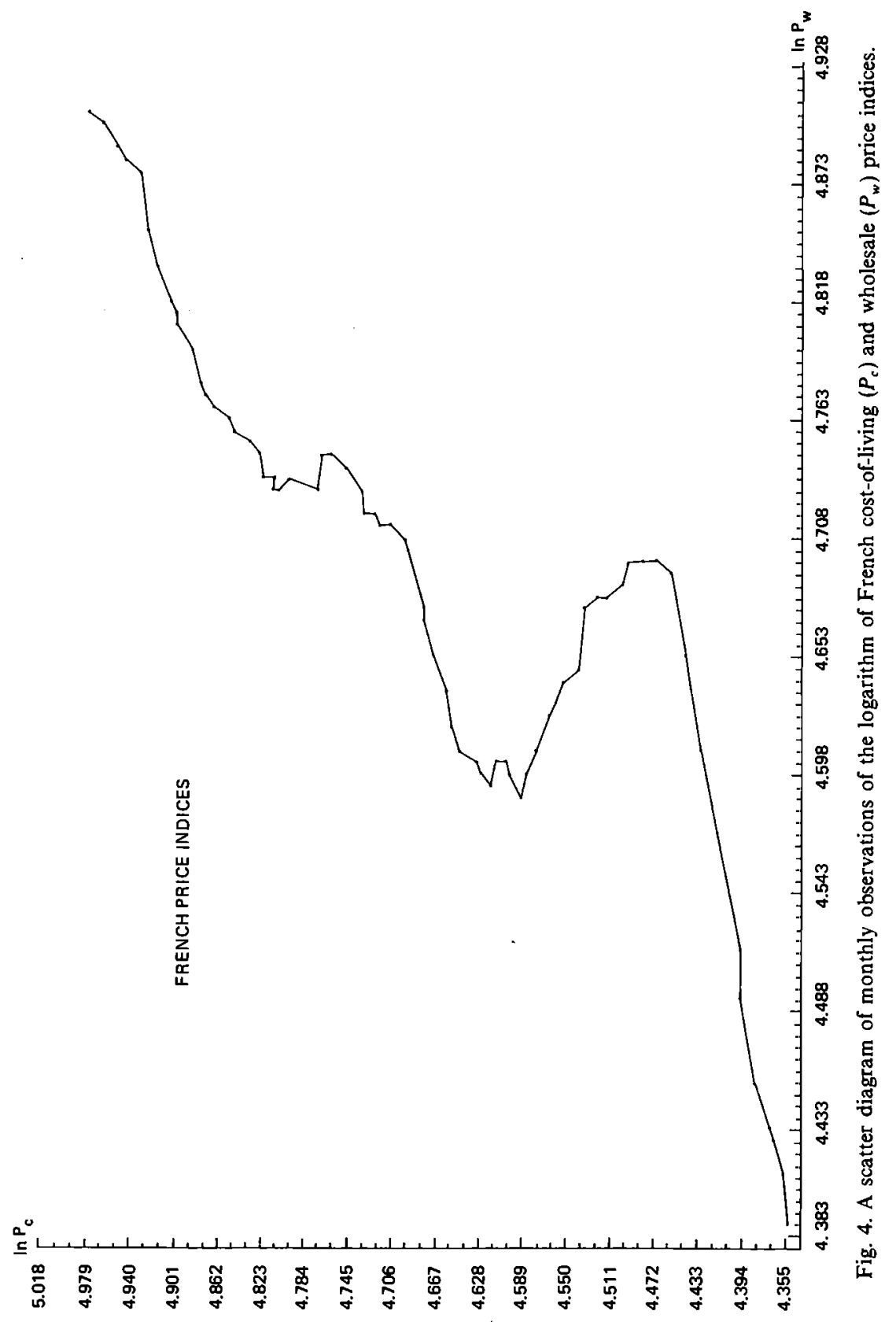




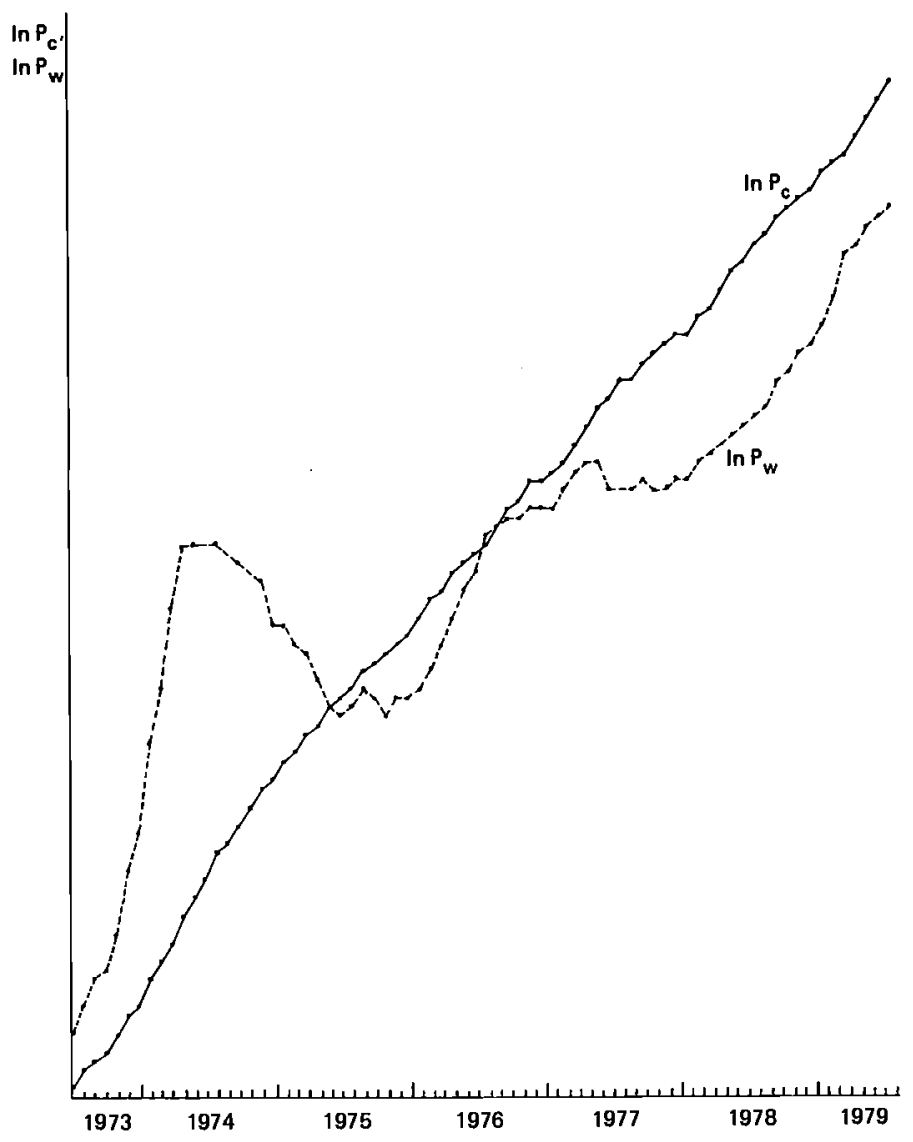

Fig. 5. Monthly observations of the logarithm of the French cost-of-living $\left(P_{c}\right)$ and wholesale $\left(P_{w}\right)$ price indices: June 1973-July 1979.

even though the exchange rate does not move in full conformity with the ratio of national price levels and changes in the exchange rate do not conform fully with inflationary differentials, the two national price levels expressed in terms of the same currency do move in conformity with each other. This is an alternative test of the PPP doctrine.

Eq. (8) formulates this idea which has been suggested by Bilson (1980),

$$
\ln P_{t}=\alpha+\beta \ln \left(S P^{*}\right)_{t}+\varepsilon_{t}
$$

where the variable $S P^{*}$ converts the foreign price index $P^{*}$ to domestic currency units. While the traditional formulation may fail due to changes in relative prices, these changes in relative prices may be less important in determining the trends of national price levels (expressed in common 
currency units) which are dominated by monetary conditions. This distinction may be potentially important for the applications of monetary models of exchange rates [e.g., the models described in Frenkel and Johnson (1978)] since in many of these models $S P^{*}$ is frequently substituted for $P$.

Table 7 reports estimates of eq. (8) for the various national price levels (converted to common currency units) using the cost-of-living and the wholesale price indices. The comparison between these results and the corresponding traditional PPP estimates of table 2 is interesting. In table 7 all the coefficients (except for the U.S./France wholesale price index) are highly significant, and analogous to the results in table 5 the link between the price levels within Europe is stronger than the link between the price levels of the U.S. and the European countries (for which the slope coefficients in table 7 are smaller than unity).

Table 7

Domestic and foreign price levels: instrumental variables, monthly data: June 1973-July 1979 (standard errors in parentheses), $\ln P=\alpha+\beta \ln \left(S P^{*}\right)+\varepsilon^{\mathrm{A}}$

\begin{tabular}{lcccccc}
\hline $\begin{array}{l}\text { Domestic country/ } \\
\text { foreign country }\end{array}$ & Constant & $\ln \left(S P_{\mathrm{r}}^{*}\right)$ & $\ln \left(S P_{\mathrm{c}}^{*}\right)$ & s.e. & $D . W$. & $\rho$ \\
\hline U.S./U.K. & 2.602 & 0.383 & & 0.014 & 1.57 & 0.919 \\
& $(0.377)$ & $(0.068)$ & & & & \\
& 3.647 & & 0.213 & 0.007 & 1.72 & 0.971 \\
& $(0.267)$ & & $(0.046)$ & & & \\
U.S./France & 4.809 & 0.027 & & 0.010 & 1.42 & 0.972 \\
& $(0.309)$ & $(0.091)$ & & & & \\
& 2.724 & & 0.616 & 0.018 & 2.24 & 0.833 \\
& $(0.197)$ & & $(0.061)$ & & & \\
U.S./Germany & 2.110 & 0.675 & & 0.023 & 1.84 & 0.793 \\
& $(0.264)$ & $(0.069)$ & & & & \\
& 2.272 & & 0.633 & 0.019 & 2.05 & 0.812 \\
U.K./Germany & $(0.230)$ & & $(0.060)$ & & & \\
& 1.070 & 1.201 & & 0.033 & 1.60 & 0.896 \\
& $(0.550)$ & $(0.174)$ & & & & \\
& 1.498 & & 1.055 & 0.029 & 1.57 & 0.910 \\
France/Germany & $(0.529)$ & & $(0.166)$ & & & \\
& 2.066 & 0.500 & & 0.011 & 1.02 & 0.913 \\
& $(0.548)$ & $(0.102)$ & & & & \\
& -0.293 & & 0.939 & 0.018 & 1.50 & 0.927 \\
\hline
\end{tabular}

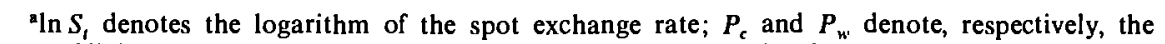
cost-of-living and wholesale price indices with an asterisk denoting foreign prices. Foreign prices are converted to domestic currency units by the corresponding exchange rate. Cochrane-Orcutt iterative technique with two-stage least squares estimation method was used; the instruments are a constant, time, time squared, and lagged values of the dependent and independent variables. s.e. is the standard error of the equation. 


\section{Exchange rates and national price levels are not comparable}

The analysis in the previous sections presumed that when inter-sectoral relative price structures remain stable and when there are no significant changes in tariffs and non-tariff barriers to trade and in the degree of capital market integration, the purchasing power parity doctrine should hold even for the short run. The major point that is being made in this section is that the modern approach to the analysis of exchange rates implies that there is a fundamental difference between the characteristics of exchange rates and those of national price levels. This difference yields a presumption that, at least in the short run, exchange rate fluctuations would not be matched by corresponding fluctuations of aggregate price levels.

The central insight of the modern approach to the analysis of exchange rates is the notion that the exchange rate, being the relative price of two durable assets (monies), can be best analyzed within a framework that is appropriate for the analysis of asset prices. A key characteristic of the price of an asset is its strong dependence on expectations concerning the future. In an efficient market for assets, new information concerning the future is reflected immediately in current prices and thus precluding unexploited profit opportunities from arbitrage. The strong dependence of current prices on expectations about the future is unique to the determination of durable asset prices which are traded in organized exchange; it does not characterize to the same extent the determination of prices of non-durable commodities (like fresh fish). The strong dependence of asset prices on expectations also implies that during periods that are dominated by 'news' which induce frequent changes in expectations, asset prices exhibit large fluctuations. Since exchange rates are viewed as asset prices, they will also exhibit a relatively large degree of volatility during periods that are dominated by 'news' which alter expectations. Since by definition the 'news' cannot be predicted on the basis of past information, it is clear that by and large the fluctuations of exchange rates are unpredictable.

In contrast to these characteristics of exchange rates, aggregate price indices are not expected to reveal such a degree of volatility since they reflect the prices of goods and services which are less durable and therefore are likely to be less sensitive to the 'news' which alter expectations about the future.

This distinction between commodity prices and asset prices is fundamental for interpreting the deviations from PPP. As is well-known, changes in commodity prices are serially correlated while changes in exchange rates are not. The 'stickiness' exhibited by commodity prices need not reflect any market imperfection but rather it may reflect the cost of price adjustment which results in finite nominal contracts. Likewise it may reflect the results of a confusion between nominal and real shocks or between permanent and transitory shocks. This, in addition to the fact that commodity price indices 
are less sensitive to changes in expectations imply that when there are frequent and significant changes in expectations as was certainly the case during the 1970's, exchange rates adjust immediately while commodity prices do not. Exchange rates reflect expectations about future circumstances while prices reflect more present and past circumstances as they are embedded in existing contracts. This difference implies that large fluctuations of exchange rates are likely to be associated with large deviations from purchasing power parities and these large deviations reflect the intrinsic difference between commodity and asset prices. ${ }^{4}$ With this perspective the recent volatility of exchange rates and the associated departures from the predictions of the PPP doctrine are much less of a mystery; they reflect the volatile character of the 1970's which witnessed great turbulence in the world economy and large volumes of real shocks like the oil embargo, supply shocks, commodity booms and shortages, shifts in the demands for money and differential productivity growth. In addition, the 1970's witnessed great uncertainty about the future course of political and economic events which induced sharp and frequent changes in expectations.

\section{Conclusions and policy implications ${ }^{5}$}

This paper analyzed the collapse of PPP during the 1970's. One of the points made in this paper was that there are circumstances during which large deviations from PPP are to be expected and that the 1970's presented an example of such circumstances. Given the expected large deviations what is left of the purchasing power parity theory and what role should it play in guiding policy? It is clear that it should not be viewed as a theory of exchange rate determination since it specifies a relationship between two endogenous variables without providing the details about the processes which bring it about. It is also clear that it does not provide a guide for dayto-day or month-to-month fluctuations of exchange rates. Further, when the economy experiences real structural changes which require adjustments of relative prices, purchasing power parities may not be satisfied even in the long run. Its usefulness is in providing a guide as to the general trend of exchange rates in particular in circumstances where the main shocks underlying the trend are of a monetary origin. As for the conduct of macroeconomic policy, it serves as an important reminder that the exchange rate and the price level cannot be divorced from each other and that policies which affect the trend of domestic (relative to foreign) prices are likely to affect the exchange rate in a similar manner.

\footnotetext{
${ }^{4}$ For further analysis of the role of expectations and 'news' in exchange rate analysis, see Dornbusch (1978), Mussa (1976, 1979), Frenkel (1981a) and Frenkel and Mussa (1980).

${ }^{5}$ The discussion in this section draws on Frenkel (1981b).
} 
Emphasis on the fact that exchange rates and prices are both endogenous variables is important in view of the recent allegations that flexible exchange rates have been inflationary. Both exchange rates and prices respond to the same set of shocks and both can be influenced by a similar set of policies. The fact that exchange rates adjust faster than commodity prices reflect the known phenomenon that asset markets clear relatively quickly. This fact does not imply that as an economic matter the chain of causality runs from exchange rates to prices.

The recognition that exchange rate fluctuations reflect the underlying circumstances rather than creating them is fundamental. It implies that, for a given conduct of macroeconomic policy the basic choice is not between costly turbulence and free tranquility but rather between alternative outlets to the underlying turbulence. If the source of evil was the variability of exchange rates, then pegging the rate would have been the simple and the feasible solution. The experience with the Bretton-Woods system indicates that this is not the case. One could argue, however, that the obligation to peg the rate would alter the conduct of policy by introducing discipline. Experience suggests, however, that national governments are unlikely to be disciplined by the exchange rate regime; rather, the exchange rate regime is more likely to adjust to whatever discipline national governments choose to have.

One of the relevant questions that remains is whether exchange rate fluctuations during the 1970's have been excessive. It should be obvious that in order to answer this question we need a standard for comparison. If a relevant yardstick is the extent of variation of national price levels, then indeed exchange rates have fluctuated excessively. For example, from June 1973 through July 1979, the average absolute monthly percentage change of the Dollar/Pound, the Dollar/French Franc and the Dollar/DM exchange rates exceeded two percent per month. In comparison the average absolute monthly percentage change for wholesale and consumer price indices and for the ratios of national price levels were only about half that of the corresponding exchange rates. As a result, adherence to a narrow interpretation of the purchasing power parity theory results in the conclusion that exchange rate variations were excessive. The asset market approach suggests, however, that a relevant yardstick should be the variations of other asset prices rather than commodity prices. During the same period the average absolute percentage change in the various stock market indices has been about twice the corresponding changes in exchange rates. By this standard exchange rates have not fluctuated excessively.

With this interpretation it seems that intervention in the foreign exchange market which ensures that exchange rates conform with purchasing power parities would be a mistaken course of policy. If commodity prices do not adjust fully in response to exogenous shocks, it seems that a large adjustment 
of exchange rates serves a useful role since it provides the outlet for the pressure which otherwise would have been reflected in commodity prices.

Government policy can, however, make a positive contribution to reducing costly and unnecessary variations of exchange rates by adopting more stable and predictable patterns of policies. This is particularly relevant in the case of exchange rates since as was argued before, current exchange rates reflect expectations concerning future events and future policies. Current policy instability may induce expectations for future policy instability and, thereby, have a magnified effect on current exchange rates. When policies are erratic and unpredictable, monetary policy exerts real side effects. Put differently, money is felt when it is out of order; when it is in order it only serves as a veil over the real equilibrium of the economy. This unique property of money is best summarized by the following quotation from John Stuart Mill:

There cannot, in short, be intrinsically a more insignificant thing, in the economy of society, than money; except in the character of a contrivance for sparing time and labour. It is a machine for doing quickly and commodiously, what would be done, though less quickly and commodiously, without it: and like many other kinds of machinery, it only exerts a distinct and independent influence of its own when it gets out of order.

Principles of Political Economy 5th edition, 1962, Book III, Ch. VII, §3

The role of policy is to ensure that money is in order and this can be achieved by following a predictable stable course of policy. Following such a course will not eliminate variations of exchange rates nor will it ensure that exchange rates conform with the predictions of the purchasing power parity theory. It will, however, reduce some of the unnecessary and costly fluctuations which are induced by unstable and erratic policies.

\section{Data appendix}

\section{A.1. Exchange rates}

The spot exchange rates are end of month rates obtained from the IMF tape (May 1979 version, updated to July 1979 using the November 1979 issue of the International Financial Statistics) obtained from the International Monetary Fund. Sources for the 1920's are indicated in Frenkel (1980).

\section{A.2. Prices}

The wholesale and cost of living price indices are period averages obtained 
from the IMF tape, lines 63 and 64, respectively. Sources for the 1920's are indicated in Frenkel (1980).

\section{A.3. Stock markets}

The stock market indices correspond to the last trading day of the month. The sources are Capital International Perspective, Geneva, Switzerland, monthly issues.

\section{References}

Bilson, John F.O., 1980, Permanent and transitory changes in international competitiveness (University of Chicago, Chicago, IL) in process.

Dornbusch, Rudiger, 1978, Monetary policy under exchange rate flexibility, in: Managed exchange rate flexibility: The recent experience, Federal Reserve Bank of Boston Conference Series no. 20.

Frenkel, Jacob A., 1978, Purchasing power parity: Doctrinal perspective and evidence from the 1920 's, Journal of International Economics 8, no. 2, May, 169-191.

Frenkel, Jacob A., 1980, Exchange rates, prices and money: Lessons from the 1920's, American Economic Review 70, no. 2, May, 235-242.

Frenkel, Jacob A., 1981a, Flexible exchange rates, prices and the role of 'news': Lessons from the 1970's, Journal of Political Economy 89, no. 4, Aug., forthcoming.

Frenkel, Jacob A., 1981b, Comments on exchange rates volatility and purchasing power parities, in: J. Dreyer, G. Haberler and T. Willett, eds., The international monetary system under stress (American Enterprise Institute, Washington, DC).

Frenkel, Jacob A. and Harry G. Johnson, eds., 1978, The economics of exchange rates: Selected studies (Addis on-Wesley, Reading, MA).

Frenkel, Jacob A. and Michael L. Mussa, 1980, The efficiency of foreign exchange markets and measures of turbulence, American Economic Review 70, no. 2, May, 374-381.

Gordon, Robert J., 1976, Recent developments in the theory of inflation and unemployment, Journal of Monetary Economics 2, 185-219.

Gordon, Robert J., 1977, Can the inflation of the 1970s be explained?, Brookings Papers on Economic Activity, no. 1, 253-277.

Katseli-Papaefstratiou, Louka T., 1979, The re-emergence of the purchasing power parity doctrine in the 1970's, Special Papers in International Economics no. 13 (Princeton University, Princet on, NJ).

Mill, John S., 1862, Principles of political economy, 5th ed. (Parker \& Co., London).

Mussa, Michael L., 1976, Our recent experience with fixed and flexible exchange rates: A comment, in: K. Brunner and A.H. Meltzer, eds., Institutional arrangements and the inflation problem, Carnegie-Rochester Conference Series on Public Policy, Vol. 3, A supplementary series to the Journal of Monetary Economics, 123-141.

Mussa, Michael L., 1979, Empirical regularities in the behavior of exchange rates and theories of the foreign exchange market, in: K. Brunner and A.H. Meltzer, eds., Policies for employment, prices and exchange rates, Carnegie-Rochester Conference Series on Public Policy, Vol. 11, A supplementary series to the Journal of Monetary Economics, 9-57.

Officer, Lawrence H., 1976, The purchasing-power-parity theory of exchange rates: A review article, International Monetary Fund Staff Papers 23, March, 1-16. 